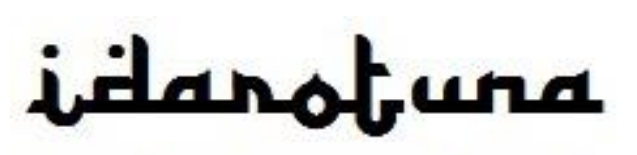

Jurnal Kajian Manajemen Dakwah
Volume 3, Nomor 2, April 2021

P-ISSN: 2654-4709

E-ISSN: 2654-4938

DOI: 10.24014/idarotuna.v3i2.12163

\title{
Komunikasi Dakwah dan Fenomena Demonstrasi Anarkis di Makassar
}

\author{
Suharto ${ }^{1}$, Mahmuddin ${ }^{2}$ \\ ${ }^{1}$ Institut Agama Islam Palu \\ ${ }^{2}$ Universitas Islam Negeri Alauddin Makassar \\ Email: suharto@iainpalu.ac.id
}

\begin{abstract}
This article aims to examine methods of da'wah communication in minimizing anarchist demonstrations and to examine the factors that hinder dakwah communication against the phenomenon of anarchist demonstrations. The method used is qualitative research, the source of which is data taken from various literatures and analyzed based on qualitative analysis. The results showed that the appropriate method of da'wah communication to minimize anarchist demonstrations was through the da'wah bil hikmah, al mauidzah and al mujadalah. Meanwhile, the factors that hindered the communication of proselytizing against the phenomenon of anarchist demonstrations were security forces acting in a repressive manner, politicizing the movement and acts of propaganda and provocation. The implication of this research is that every demonstration should prioritize common sense so that anarchists do not occur.
\end{abstract}

Keywords: da'wah communication, demonstration, anarchist

\begin{abstract}
Abstrak: Artikel ini bertujuan untuk mengkaji metode komunikasi dakwah dalam meminimalisasi demonstrasi anarkis dan mengkaji faktor-faktor yang menghambat komunikasi dakwah terhadap fenomena demonstrasi anarkis. Metode yang digunakan adalah penelitian kualitatif yang sumber datanya diambil dari berbagai literatur dan dianalisis berdasarkan analisis kualitatif. Hasil penelitian menunjukkan bahwa metode komunikasi dakwah yang tepat digunakan dalam rangka meminimalisir demonstrasi anarkis adalah melalui dakwah bil hikmah, al mauidzah dan al mujadalah. Sedangkan faktor-faktor yang menghambat komunikasi dakwah terhadap fenomena demonstrasi anarkis adalah aparat keamanan yang bertindak represif, politisasi gerakan dan tindakan propaganda dan provokasi. Implikasi penelitian ini adalah seyogyanya pada setiap demonstrasi sebaiknya mengedepankan akal sehat agar tidak terjadi anarkis.
\end{abstract}

Kata kunci: Komunikasi Dakwah, Demonstrasi, Anarkis

\section{Pendahuluan}

Di zaman era globalisasi sekarang ini, ada banyak cara yang bisa dilakukan dalam melaksanakan suatu gerakan dakwah. Berbeda pada waktu ketika manusia belum menggunakan media komunikasi bahkan belum mengenal teknologi. Pada saat sekarang ini, banyaknya akun media sosial yang dimiliki seseorang untuk berkomunikasi, bahkan sosial media sebagai sebuah lifestyle. Dengan melalui media sosial, maka pesan-pesan dakwah dapat disebarluaskan dengan mudah dan efektif bahkan seperti ayat-ayat al-qur'an, tulisan-tulisan bisa menjangkau sampai ke 
seluruh penjuru dunia. Sebagaimana diketahui bersama bahwa dakwah adalah salah satu kewajiban yang harus dilakukan sebagai setiap muslim meskipun menyampaikannya hanya dengan satu ayat.

Salah satu ilmu yang pertama yang dimiliki manusia adalah komunikasi. Komunikasi adalah proses pengiriman atau penyampaian berita atau informasi dari satu pihak ke pihak lain dalam usaha untuk mendapatkan saling pengertian (Ngalimun, 2017). Manusia berinteraksi dengan manusia yang lain dengan cara berkomunikasi. Tanpa komunikasi manusia tidak dapat berkembang, bisa dibayakngkan jika manusia tanpa komunikasi, maka kehidupan dunia ini akan terasa sepi. Manusia sebagai makhluk sosial akan selalu membutuhkan komunikasi dengan orang lain untuk berinterkasi dan berkomunikasi. Berinteraksi dengan sesama manusia adalah sebagai bentuk eksistensi dan pengukuhan diri bahwa manusia terus berkembang dan mengalami kemajuan.

Dakwah merupakan aktivitas manusia yang tiada akhir, sepanjang manusia hidup di dunia ini dan sebuah kewajiban dalam agama yang harus dilaksanakan. Dalam kehidupan seharihari, dakwah banyak dipahami di sebagian kalangan muslimin sebagai makna yang sempit yaitu dengan ceramah atau pidato yang identik dengan mimbar yang berada di masjid. Oleh karena itu, maka pemahaman seperti ini membutuhkan penjelasan yang cukup efektif sehingga dapat merubah pemahaman bahwa sesungguhnya dakwah bermakna luas.

Pada dasarnya dakwah sebagai suatu kegiatan yang mengajak atau menyeru dan memanggil. Dakwah mengandung pengertian yang lebih luas dari istilah tersebut, karena dakwah mengandung makna sebagai aktivitas menyampaikan ajaran islam, menyuruh berbuat baik dan mencegah perbuatan mungkar, serta memberi kabar gembira dan peringatan bagi manusia. (Munir \& Ilahi, 2015). Oleh karena itu, sejatinya dakwah haruslah membawa kabar gembira dan bukan menakut-nakuti kepada manusia.

Komunikasi dakwah pada umumnya mengharapkan partisipasi dari komunikasi atas ideide atau pesan- pesan yang disampaikan oleh pihak komunikator sehingga pesan-pesan yang disampaikan tersebut terjadi perubahan sikap dan tingkah laku yang diharapkan dan perubahan sikap atau tingkah laku tersebut sesuai dengan ajaran agama Islam. oleh karena itu, dengan komunikasi dakwah dapat mengurangi atau meminimalisir terjadinya hal-hal yang tidak diinginkan seperti dalam fenomena aksi demonstrasi yang anarkis.

Di era pasca runtuhnya orde baru, maka muncul era reformasi seperti saat ini, dengan kondisi bangsa yang serba carut marut seperti sekarang ini menjadi sebuah tantangan bagi mahasiswa dalam mengawal jalannya roda demokrasi. Partisipasi mahasiswa sangat dibutuhkan dalam terciptanya demokrasi yang bersih serta memperjuangkan hak-hak rakyat yang tertindas oleh kebijakan pemerintah yang tidak pro terhadap masyarakat kalangan bawah.

Salah satu cara dalam menyampaikan aspirasi masyarakat adalah dengan melalui unjuk rasa atau demonstrasi. Demonstrasi dilakukan dengan cara melakukan protes dengan sekumpulan orang di depan publik dengan sebuah tujuan gerakan moral. Unjuk rasa atau demonstrasi adalah gerakan yang wajar dan telah diatur oleh undang-undang di Negara Republik Indonesia (Pasal 4 Undang-Undang Nomor 9 Tahun 1998) tentang Kemerdekaan Menyampaikan Pendapat di Muka 
Umum, yang berbunyi : (a) Mewujudkan kebebasan yang bertanggung jawab sebagai salah satu pelaksanaan hak asasi manusia sesuai dengan Pancasila dan UU. NRI Tahun 1945, (b) Mewujudkan perlindungan hukum yang konsisten dan berkesinambungan dalam menjamin kemerdekaan menyampaikan pendapat, (c) Mewujudkan iklim yang kondusif bagi berkembangnya partisipasi dan kreativitas setiap warga negara sebagai perwujudan hak dan tanggung jawab dalam kehidupan berdemokrasi, (d) Menempatkan tanggung jawab sosial dalam kehidupan bermasyarakat, berbangsa, dan bernegara, tanpa mengabaikan kepentingan perorangan atau kelompok.

Dalam proses unjuk rasa terkadang dapat menyebabkan terjadinya pengrusakan terhadap benda-benda, fasilitas dan lainnya yang berujung pada aksi anarkis. Oleh karena itu, untuk meminimalisasi terjadinya aksi demonstrasi yang berujung pada aksi anarkis yang dilakukan oleh sekelompok massa, maka dibutuhkan komunikasi dakwah yang baik dan efektif.

\section{Metode}

Objek kajian ini ilmiah ini adalah kajian tentang komunikasi dakwah dan fenomena demonstrasi anarkis. Oleh karena itu, maka penulis menggunakan penelitian lapangan atau field research kualitatif. Penelitian dalam artikel ini adalah menggunakan jenis penelitian kualitatif yakni penelitian yang berdasarkan peristiwa yang terjadi di lapangan sesuai dengan kenyataan yang terjadi dan suatu penelitian yang belum pernah diteliti sebelumnya terkait komunikasi dakwah dan fenomena demonstrasi anarkis. Lokasi penelitian ini dilakukan di Kota Makassar yaitu mahasiswa dan LSM dan ormas lainnya. Pemilihan lokasi ini berdasarkan pertimbangan bahwa kota makassar sebagai ibu kota provinsi dan sentrum Gerakan di Provinsi Sulawesi Selatan dan menggunakan pendekatan komunikasi dakwah karena dinilai sebagai cara yang cukup efektif dalam meminimalisir terjadinya demonstrasi anarkis.

Pendekatan normatif yaitu pendekatan yang digunakan untuk menganalisah antara pembahasan yang berkaitan dengan Qur'an dan hadis sebagai landasan normatif dalam Islam terkait dengan komunikasi dakwah dan fenomena demonstrasi anarkis. Pendekatan komunikasi yaitu pendekatan yang dilakukan manusia yng selama ini dalam menjalani kehidupan senantiasa melakukan proses interaksi antara manusia dengan manusia lainnya. Pendekatan dakwah yaitu pendekatan yang mengindikasikan bahwa manusia adalah makhluk ciptaan Tuhan yang memerlukan bimbingan dan pengarahan melalui proses dakwah.

Data primer adalah sejumlah keterangan atau fakta yang langsung diperoleh dari subjek peneliti di lapangan menggunakan metode wawancara data dan langsung pada subjek sebagai informan. Dalam hal ini informan utuma adalah ketua Lembaga kemahasiswaan baik intra maupun ekstra, ketua LSM dan ketua Lembaga ormas. Data sekunder adalah data yang diperoleh dari pihak lain atau data tidak langsung yang diperoleh dari subjek lainnya. Data sekunder biasanya berupa dokumen, arsip yang berhubungan dengan penelitian yang berkaitan demonstrasi yang berasal dari data-data sebelumnya.

Menurut Suharsimi Arikunto, Observasi adalah suatu teknik pengumpulan data yang dilakukan dengan cara mengadakan makalah secara teliti, secara pencatatan secara sistematis 
(Gunawan, 2016). Metode ini digunakan peneliti untuk melihat langsung secara dekat dengan cara mengamati serta melibatkan diri dengan situasi yang diselidiki. Menurut Setyadin, wawancara adalah suatu percakapan yang diarahkan pada suatu masalah tertentu dan merupakan proses tanya jawab lisan dimana dua orang atau lebih berhadapan secara fisik. (Gunawan, 2016). Wawancara ini dilakukan dengan cara tanya jawab berdasarkan pedoman yang ditujukan kepada informan. Yang dimaksud dengan dokumentasi dalam makalah ini adalah dokumen yang berasal dari para pelaku demonstrasi di kota makassar. Di dalam melakukan analisis data peneliti mengacu kepada tahapan yang dijelaskan Miles dan Huberman, sebagaimana dikutip Sukmadinata yang terdiri dari tiga tahapan dalam Teknik pengolahan dan analisis data yaitu (Sukmadinata, 2006).

Reduksi data adalah proses pemilihan, pemusatan perhatian pada penyederhanaan, pengabstrakan dan informasi data kasar yang muncul dari catatan yang ditulis di lapangan. Dalam proses ini berlangsung selama dalam dan sesudah penelitian dilakukan di lapangan. Penyajian data ini adalah proses pemberian sekumpulan informasi yang tersusun sehingga memberikan kemungkinan untuk penarikan kesimpulan dan pengambilan tindakan. Data yang telah direduksi dan disajikan kemudian disimpulkan. Penarikan kesimpulan ini merupakan suatu kegiatan konfigurasi yang utuh dan terus diverifikasi selama penelitian berlangsung.

Bagian metode berisi paparan dalam bentuk paragraf tentang rancangan penelitian, sumber data, teknik pengumpulan data, dan analisis data. Bagian metode berisi paparan dalam bentuk paragraf tentang rancangan penelitian, sumber data, teknik pengumpulan data, dan analisis data.

\section{Hasil dan Pembahasan}

\section{Metode Komunikasi Dakwah dalam Meminimalisir Demonstrasi Anarkis}

Sebelum lebih jauh membahas tentang metode komunikasi dakwah dalam meminimalisir demonstrasi anarkis, maka terlebih dahulu dikemukakan beberpa pengertian, yaitu kata atau istilah komunikasi dari bahasa inggris communication, secara etimologi atau menurut asal katanya adalah dari bahasa latin commucatus, dan perkataan ini bersumber pada kata communis. Dalam kata communis sini memiliki makna "berbagi" atau 'menjadi milik bersama' yaitu suatu usaha yang memiliki tujuan atau kebersamaan atau kesamaan makna. (Ngalimun, 2017). Komunikasi sebagai proses dalam menyampaikan pesan secara langsung dalam menjalin hubungan kepada sesesorang atau suatu kelompok baik yang bersifat umum maupun khusus.

Komunikasi secara terminologis merujuk pada adanya proses penyampaian suatu pernyataan oleh seseorang kepada orang lain. Jadi dalam pengertian ini yang terlibat dalam komunikasi adalah manusia. Bahwa komunikasi manusia adalah proses yang melibatkan individu-individu dalam suatu hubungan, kelompok, organisasi dan masyarakat yang mersepon dan menciptakan pesan untuk berpartisipasi dengan lingkungan satu sama lain (Ngalimun, 2017). Dalam proses komunikasi melibatkan manusia dan kelompok sehinga tercipta proses komunikasi yang efektif. Komunikasi yang efektif dapat terjalin dengan baik apabila kedua belah 
pihak saling mengakui kekurangan dan kelebhan orang lain serta mengerti kelemahan orang masing-masing.

Menurut Everett M. Rogers seorang pakar sosiologi mengatakan bahwa komunikasi adalah proses di mana suatu ide dialihkan dari sumber kepada satu penerima atau lebih, dengan maksud untuk mengubah tingkah laku mereka. (Cangara, 2016). Dalam proses komunikasi salah satu tujuannya adalah mengubah tingkah laku seseorang.

Menurut D. Lawrence Kincaid bahwa komunikasi adalah suatu proses di mana dua orang atau lebh membentuk atau melakukan pertukaran informasi dengan satu sama lainnya, yang pada gilirannya akan tiba pada saling pengertian yang mendalam. (Cangara, 2016). Maka, untuk saling memahami antara satu sama lain dibutuhkan komunikasi dan informasi yang baik.

Oleh karena itu, dalam situasi berkomunikasi mempunyai tujuan yaitu untuk saling memahami baik daeri segi bahasa, simbol maupun secara sosial sehingga komunikasi dapat berjalan lancar dan efektif.

Kata dakwah berasal dari bahasa Arab دعا- يدعو - دعوة (daá>, yadú>, da'watan) berarti memanggil, mengajak, berdoa, mengundang. Kata ini, dapat bermakna positif dan bermakna negatif. Makna positif kalau untuk diarahkan kepada kebaikan sedang makna negatif kalau diarahkan kepada kejahatan atau perbuatan setan (Seha, 2012). Dakwah sebagai usaha untuk mengajak manusia ke arah proses yang lebih baik agar menjadi menjadi manusia yang terbaik. Dalam Al-Qur'an Allah swt berfirman dalam Q.S. Ali Imran ayat 110 yang berbunyi:

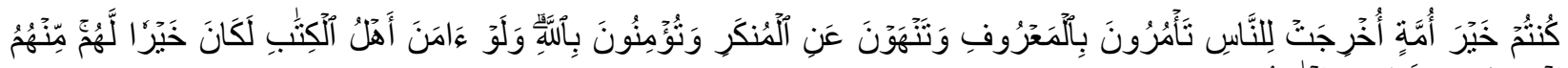

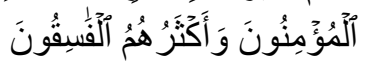

Artinya:

Kamu adalah umat yang terbaik yang dilahirkan untuk manusia, menyuruh kepada yang ma'ruf, dan mencegah dari yang munkar, dan beriman kepada Allah. sekiranya ahli Kitab beriman, tentulah itu lebih baik bagi mereka, di antara mereka ada yang beriman, dan kebanyakan mereka adalah orang-orang yang fasik (Al-Qur'an Surah Ali Imran ayat 110).

Sebagaimana ayat di atas, maka umat yang terbaik adalah mereka yang menyeru kepada yang ma'ruf dan mencegah dari yang munkar serta beriman kepada Allah swt. agar tercipta manusia yang berpribadi yang baik serta mampu menjadikan kualitas hidup menjadi lebih baik. Dalam menjalankan misi dakwah, roda kehidupan harus menjadi patron utama agar tercipta keselarasan hidup bagi umat manusia.

Menurut Abu Bakar Zakaria sebagaimana yang dikutip oleh Arifuddin Tike dalam bukunya Dakwah dan Pengembangan Masyarakat Islam memberikan penjelasan bahwa dakwah ialah usaha para ulama dan orang-orang yang memiliki ilmu pengetahuan tentang agama (Islam) untuk memberi pengajaran kepada khalayak (masyarakat) hal-hal yang dapat menyadarkan mereka tentang urusan agama dan urusan dunianya sesuai dengan kemampuannya (Arifuddin Tike, 2011). Dalam usaha dakwah manusia diarahkan kepada hal-hal yang berkaitan dengan urusan dunia dan khususnya akhirat sebagai tujuan akhir dari kehidupan manusia setelah mati. 
Dakwah menurut Bakhyul Khuly sebagaimana yang dikutip oleh Arifuddin Tike dalam bukunya Dakwah dan Pengembangan Masyarakat Islam adalah memindahkan umat dari satu situasi ke situasi yang lain. Dakwah yang dimaksud adalah suatu aktivitas atau perubahan kea rah yang lebih baik dari aktivitas manusia baik dari segi agama, ekonomi, pendidikan, sosial budaya, politik dan lain-lain. Salahuddin Sanusi mengemukakan; dakwah dapat diartikan Islam yaitu usaha-usaha perbaikan dan pembangunan masyarakat; memperbaiki kerusakan-kerusakan, melenyapkan kebatilan, kemaksiatan dan ketidakwajaran dalam masyarakat (Arifuddin Tike, 2011). Dalam rangka perbaikan itu maka dakwah sebagai proses penyambung dalam kebaikan untuk kehidupan masyarakat yang lebih baik.

Ali Makhfudh dalam kitabnya "hidayatul mursyidin" sebagaimana yang dikutip oleh Muhammad Munir dalam buku Manajemen Dakwah mengatakan bahwa dakwah adalah mendorong manusia untuk berbuat kebajikan dan mengikuti petunjuk (agama), menyeru kepada kebaikan dan mencegah mereka dari perbuatan mungkar agar memperoleh kebahagiaan dunia dan akhirat (Munir dan Ilahi, 2015). Dalam memahami ajaran Islam maka dakwah sebagai pendorong manusia agar terhindar dari pengaruh yang dapat mengakibatkan rusaknya sistem tatanan dalam kehidupan manusia.

\section{Demonstrasi dan Anarkis}

Demonstrasi adalah kegiatan yang dilakukan oleh seorang atau lebih untuk mengeluarkan pikiran dengan lisan, tulisan dan sebagainya secara demonstratif di muka umum (Abdussalam, 2006). Kegiatan ini umunya dilakukan oleh mahasiswa, ormas, buruh atau Lembaga kemasyarakatan lainnya dengan tujuan untuk meyampaikan aspirasi terhadap suatu kebijakan yang dapat merugikan seseorang maupun kelompok.

Demonstrasi merupakan kegiatan menyatakan pendapat di muka umum sebagai salah satu hak-hak asasi manusia (HAM). Ia merupakan hak kemerdekaan dasar yang dimiliki setiap manusia sejak dilahirkan ke dunia yang harus mendapat jaminan hukum yang adil dari negera. Di indonesia sendiri, kemerdekaan berpendapat merupakan perwujudan dari sila ke-4 pancasila yaitu kerakyatan yang dipimpin oleh hikmat kebijaksanaan dalam permusyawaratan perwakilan. Kemudian di dalam undang-undang dasar pasal 28 menegaskan bahwa "kemerdekaan berserikat dan berkumpul mengeluarkan pikiran dengan lisan dan tulisan dan sebagainya ditetapkan dengan undang-undang" (Abdussalam, 2006). Dalam menyampaikan aspirasi di depan umum merupakan setau yang wajar dan telah diatur dan dilindungi dalam undangn-undang sehingga rakyat indonesia bebas dalam menyampaikan pendapatnya.

Menurut Noam Chomsky, anarkisme sebagai pemikiran maupun praksis memiliki sangat banyak bentuk dan karakteristik. Sangat susah untuk memberikan batasan-batasan ketat terhadap seluruh tendensi-tendensi konfliktual dalam teorinya secara umum maupun secara idiologi. Chomsky menambahkan bahwa sekalipun dibuat suatu ekstrasi dari sejarah pemikiran libertian dan secara teliti mengembangkan tradisi-tradisinya, tetaplah sulit untuk memformulasikan doktrin-doktrin anarkisme sebagai sebuah teori tentang masyarakat dan perubahan sosial yang spesifik dan determinan (Chomsky, 1970). Jadi, dalam teori aksi anarkisme merupakan sebuah 
tujuan untuk melakukan sebuah perubahan sosial dalam masyarakat dengan melalui tradisitradisi sebelumnya.

Chomsky merujuk pada konsepsi Rudolf Rocker, seorang sejarawan anarkis. Menurut Chomsky, Rocker mempresentasikan konsepsi yang sistematis mengenai perkembangan pemikiran anarkis melalui anarcho-syndicalism, yang menuliskan bahwa anarkisme bukanlah "suatu sistem sosial yang baku dan tertutup, melainkan sebuah tren pasti dalam perkembangan sejarah umat manusia yang berkebalikan dengan penjagaan intelektual oleh semua lembaga pemerintah dan keagamaan. Anarkisme mendambakan pelepasan bebas tanpa batas semua kekuatan individual dan sosial dalam kehidupan. Bahkan kebebasan pun adalah konsep yang relatif, bukan absolut, karena terus menerus meluas dan mempengaruhi kelompok-kelompok lain dengan cara-cara yang lebih beraneka macam. Bagi seorang anarkis, kebebasan bukanlah konsep filosofis abstrak, melainkan peluang konkret vital bagi setiap manusia untuk mengembangkan sepenuhnya segala daya, kapasitas, dan talenta yang telah di berikan alam kepadanya, dan mengubahnya menjadi perangkat sosial. Makin sedikit perkembangan alami manusia ini dipengaruhi oleh penjagaan keagamaan maupun politik, makin efisien dan harmonislah kepribadian manusia itu nantinya. Ia pun akan semakin menjadi tolok ukur budaya intelektual masyarakat tempatnya tumbuh" (Chomsky, 1970).

Indonesia sebagai sebuah bangsa yang besar yang berasakan pancasila dengan menjunjung tinggi demokrasi sebagai inti kehidupan bermasyarakat. Demontrasi sebagai ekspresi kebebasan bersuara dan berpendapat sangat diperlukan di negara demokrasi seperti Indonesia. Demonstrasi menandakan bahwa masyarakat masih hidup untuk menentukan nasibnya di tengah kegalauan politiknasional yang kian memanas. Masyarakat masih bersuara lantang di tengah hiruk pikuk politik para penguasa negeri ini. Sejarah perkembangan demokrasi bangsa Indonesia sudah sepatutnya mengalami perubahan jika dibandingkan dengan zaman orde baru dengan zaman reformasi sekarang ini. Jika zaman orde lama menegluarkan pendapat sangatlah susah, maka zaman sekarang mengelurkan pendapat bisa dengan bebas dilakukan.

Jika kita melihat bahwa aksi demontrasi yang dilakukan oleh mahasiswa, buruh terkait isu kenaikan BBM, dan yang terakhir ini adalah demonstrasi revisi Undang-undang KPK, revisi undang-undang KUHP dan Omnibus Law menjadi sebuah penanda sebagai kebebasan berekspresi dan menyampaikan pendapat di muka umum dan bentuk kritik terhadap pemerintah. akan tetapi demontrasi yang dilakukan mahasiswa, masyarakat dan buruh menjadi korban akibat terjadinya anarkisme yang dilakukan oleh beberapa oknum yang tidak bertanggung jawab.

Krisis idealitas aksi demontrasi ini merupakan sebauah kecemasan tersendiri bagi proses demokrasi di negeri ini. Karena bagaimanapun, demo disertai dengan tindakan anarkis memang tidak boleh dibiarkan. Selain menodai perjuangan para pendemo, anarkis serta merusak fasilitas umum maupun pribadi tentunya akan mengakibatkan kerugian yang tidak sedikit karena secara tidak langsung akan merugikan pribadi dan masyarakat umum.

Jadi, yang dimaksud dengan komunikasi dakwah dengan fenomena demonstrasi anarkis adalah bahwa suatu proses penyampaian informasi atau pesan dari seseorang atau suatu kelompok orang kepada seseorang atau sekelompok orang lain yang bersumber dari Al-Qur'an 
dan hadis dengan menggunakan lambang-lambang baik secara verbal maupun nonverbal untuk merubah suatu tatanan sosial melalui pikiran dan intelektual.

Setelah dipahami tentang komunikasi, dakwah dan demonstrasi serta anarkis, maka selanjutnya dibahas tentang metode komunikasi dakwah dalam meminimalisir demonstrasi anarkis. Landasan umum bentuk metode dakwah adalah Al-Qur'an dan hadis, terutama metode dakwah yang terdapat dalam Al-Qur'an pada surah An-Nahl ayat 125. Dalam ayat tersebut menjelaskan tiga metode yang digunakan dengan melihat kondisi objek dakwah yaitu:

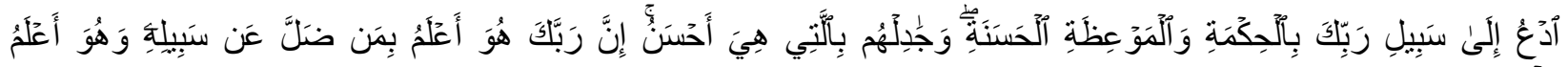

Artinya:

Serulah (manusia) kepada jalan Tuhanmu dengan hikmah dan pengajaran yang baik, dan berdebatlah dengan merka dengan cara yang baik. Sesungguhnya Tuhanmu, dialah yang lebih mengetahuisiapa yang sesat dari jalan-Nya dan Dialah yang lebih mengetahui siapa yang mendapat petunjuk (Qurán surah al-Nahl ayat 125).

Dalam surah An-Nahl ayat 125, menjelaskan tentang metode dakwah yang meliputi, alhikmah, al-mauizah al-hasanah dan al-mujadalah. Oleh karena itu, dalam pembahasan ini akan dijabarkan tentang metode dakwah tersebut.

Kata hikmah seringkali diucapkan dan diterjemahkan sebagai arti bijaksana yaitu suatu pendekatan sedemikian rupa sehingga obyek dakwah mampu melaksanakan berdasarkan yang didakwahkan dan dapat berubah sesuai dengan kemauannya sendiri tanpa adanya paksaan dari siapa pun itu. Salah satu cara yang dilakukan oleh seorang dai adalah mengubah pola pikir serta memberikan kegiatan sosialisasi dengan melibatkan berbagai elemen, stakeholder sebagai langkah yang bijaksana.

Dakwah bi al-Hikmah adalah sebuah metode komunikasi dakwah yang bersifat persuasif yang bertumpu pada human oriented sehingga konsekuensi logisnya adalah pengakuan terhadap hak-hak yang bersifat demokratis agar fungsi dakwah yang bersifat informatif dapat diterima dengan baik (Sukayat, 2015). Dakwah ini berorientasi ke manusia sehingga apabila terjadi perubahan maka, murni dari dalam diri sendiri tanpa adanya faktor dari luar yang mempengaruhinya.

Metode dakwah ini harus dilakukan dengan cara persuasif dan dalam menjalankan dakwah dapat menggunakan dalil yang dapat menjelaskan kebenaran sehingga dapat menghilangkan keraguan. Bi al-Hikmah merupakan kemampuan seorang dai dalam menyelaraskan teknik dakwah dengan kondisi madú. Sebagaimana madú yang berada yang menjadi sasaran para dai (demonstran) akan sangat berbeda dengan madú yang umumnya di masjid.

Dakwah bi al-Hikmah mempunyai peran yang sangat penting dalam menentukan sukses atau tidaknya suatu kegiatan dakwah. Oleh sebab itu, maka al-hikmah adalah suatu bekal yang harus dimiliki seorang dai (demonstran) dalam menentukan suksesnya kegiatan dakwah karena 
pada dasarnya tidak semua dai (demonstran) memiliki kemampuan bi al-hikmah sebab itu adalah karunia yang diberikan Tuhan kepada seorang dai (demonstran).

Di zaman sekarang, dalam menghadapi demonstran yang semakin kritis dan kompleks, maka tantangan yang dihadapi juga semakin komplek, maka dari itu dibutuhkan suatu strategi dakwah yang sesuai dengan kondisi. Adapun metode al-hikmah yang dilakukan demonstran adalah meliputi sebagai berikut:

Menurut kamus besar bahasa Indonesia (KBBI), bijaksana adalah selalu menggunakan akal budinya (pengalaman dan pengetahuan). Maksdunya adalah bahwa bijaksana lahir bedasarkan atas pengalaman hidup yang dilalui seseorang dengan berbagai macam tantangan dalam kehidupan sehari-hari dan mengambil pelajaran dari pengalamn tersebut dan pengetahuan yang dimaksud adalah orang yang mempunya ilmu yang di dapatkan baik dari pendidikan formal maupun nonformal karena umumnya orang yang bijaksana lahir dari ketinggian dan kedalaman ilmu ibarat pepatah "semakin berisi semakin merunduk" artinya bahwa orang yang mempunya ilmu akan cenderung tidak memperlihatkan kecerdasanya bedasarkan kata-kata akan tetapi dari perbuatan yang mencerminkan sikap hidupnya.

Bijaksana bukan pula bentuk kepandaian namun terkadang kepandaian seseorang (dai) demonstranturut membantu dalam sikap bijaksananya. Orang bijaksana dianggap cerdas karena mampu mengambil keputusan yang tepat berdasarkan situasi dan kondisi.

Orang yang bijaksana mampu menyesuaikan dan menepatkan diri dalam segala hal bahkan dalam keadaan yang sedang terjadi. Orang yang bijaksana dapat mengambil keputusa yang tepat, adil dan baaik sehingga tidak merugikan diri sendiri bahkan terhadap orang lain.

Persuasi adalah komunikasi yang bertujuan untuk mengubah atau mempengaruhi kepercayaan, sikap, dan perilaku seseorang sehingga bertindak sesuai dengan apa yang diharapkan oleh komunikator. Tindakan seorang komunikator mampu mempengaruhi keadaan komunikan berdasarkan hasil dari tindakan maupun perkataan yang bisa merubah tergantung situasi dan kondisi.

Dalam suatu kondisi, langkah persuasif dipercaya dapat mempengaruhi sikap seorang dai (demonstran) yang pada akhirnya mempengaruhi perilaku dan tindakan seorang dai (demonstran) terhadap sesuatu. Dengan langkah persuasif ini dapat mengubah pengetahuan seseorang sehingga dapat dipercaya dan dapat mengubah perilaku.

Oleh karena itu, maka seorang dai (demonstran) harus menggunakan metode al-hikmah dalam upaya mengubah persepsi dan anggapan bahwasanya untuk meminimalisir terjadinya kekacauan dan anarkis dibutuhkan kebijaksanaan dalam perkataan sehingga mampu menyentuh hati dan diterima dengan akal sehat.

Salah satu metode dalam komunikasi dakwah adalah metode al-mauzah al-hasanah yang berarti cara memberi pengajaran yang baik. Dalam pemaknaannya bahwa al-mauizah al-hasanah dalam al-qurán tertuju pada peringatan yang baik sehingga orang terdorong untuk berbuat baik.

al-Maizah al-Hasanah adalah memberikan nasihat yang baik kepada orang lain dengan cara yang baik, yaitu petunjuk-petunjuk ke arah kebaikan dengan bahasa yang baik, dapat diterima, berkenaan di hati, lurus pikiran sehingga pihak yang menjadi objek dakwah dengan rela hati dan 
atas kesadaran sendiri dapat mengikuti ajaran yang disampaikan. Dakwah bukanlah propaganda (Muriah, 2000: 43). Hal-hal yang berkaitan dengan dakwah sifatnya mengajak yang berisikan nilai-nilai islam tidak akan membuat suatu hal yang dapat menimbulkan kekacauan.

Metode dakwah al-Mauizah al-Hasanah dilakukan dengan perintah dan larangan disertai dengan motivasi (targhib) dan ancaman (tarhib) yang dutarakan lewat perkataan yang dapat melembutkan hati, pengunggah jiwa dan mencairkan segala bentuk kebekuan hati, serta dapat menguatkan keimanan dan petunjuk yang mencerahkan (Humaid, 2013: 204). Meskipun dalam prosesnya terdapat larangan akan tetapi bahwa dakwah mampu memberikan pencerahan dan ketenangan sehingga mampu mengubah seseorang.

Nasihat yang baik adalah suatu perkataan sebagai simbol komunikasi yang dapat menumbuhkan kesadaran jiwa. Dalam prosesnya perkataan yang baik dapat bermanfaat sebagai pendidikan dan memberikan penyadaran sehingga mampu membekas di hati baik orang yang pembicara maupun penerima.

Dalam menghadapi demonstran yang semakin kritis dan kompleks, maka tantangan yang dihadapi juga semakin komplek, maka dari itu dibutuhkan suatu strategi dakwah yang sesuai dengan kondisi. Adapun metode al-mauizah al-hasanah yang dilakukan demonstran adalah meliputi sebagai berikut:

a. Dakwah Tidak mengandung SARA

Isu sara menjadi hal yang sensitif akhir-akhir ini di Indonesia. Banyaknya terjadi kasus sara sehingga banyak orang yang di seret ke pengadilan. Isu sara yang terjadi menjadi sebuah ancaman besar terhadap keutuhan bangsa dan negara yang dimanfaatkan oleh orang-orang yang tidak bertanggung jawab.

SARA adalah akronim atau singkatan dari suku, agama ras dan antargolongan. Sara adalah pandangan maupun tindakan yang didasari dengan pikiran sentimen mengenai identitas diri yang menyangkut keturunan, agama, kebangsaan atau kesukuan dan golongan. Yang digolongkan sebagai sebuah tindakan sara adalah segala macam bentuk tindakan baik verbal maupun nonverbal yang didasarkan pada pandangan sentimen tentang identitas diri atau golongan (Liputan6.com). Pandangan sentimen ini yang dapat menimbulkan konflik yang berakibat pada perpecahan dalam kelompok masyarakat sehingga mempengaruhi kehidupan berbangsa dan bernegara.

Dalam aksi demonstari, seorang dai (demonstran) selayaknya dalam menyampaikan orasi politiknya harus menyampaikan kata-kata yang baik dan menyejukkan meskipun mengandung kalimat kritik dan tetap menghindari perkataan yang dapat menimbulkan sara sehingga terjadi aksi anarkis karena menyinggung hal pribada kepada yang dikritik.

\section{b. Mengubah Perilaku Sosial}

Salah satu tujuan dari dakwah al-mauizah al-hasanah adalah mengubah perilaku. Sebagian orang menganggap bahwa demonstrasi adalah kegiatan yang buruk akan tetapi jika aksi demonstarsi tersebut tidak menimbulkan hal-hal yang dapat merugikan masyarakat khsususnya di jalan raya. 
Dalam negara demokrasi seperti di Indonesia, aksi demonstarsi menjadi hal yang biasa dan lazim terjadi. Aksi demonstasi ini diperbolehkan asalkan memenuhi syarat aturan yang berlaku. Seperti tidak mengganggu ketertiban umum dan merugikan banyak orang yang mengakibatkan timbulnya kerusakan.

Demonstrasi disisi lain adalah bertujuan untuk mengubah perilaku sosial. Maksudnya bahwa aksi demonstrasi ini terjadi karena adanya ketidakadilan yang dirasakan baik dari segi ekonomi, politik bahkan sosial. Maka dari itu, tindakan demonstrasi ini harus dengan metode almauizah al-hasanah sehingga tujuan yang ditarget bisa tercapai yaitu dengan merubahnya perilaku sosial di masyarakat.

\section{c. Al-Mujadalah}

Terdapat berbagai metode dalam dakwah islam sehingga umat islam dapat tumbuh menjadi pesat seeprti sekarang ini. Salah satu metode dakwah yang digunakan oleh umat islam adalah metode al-Mujadalah. Mujadalah adalah berdiskusi dengan cara yang baik dari cara-cara diskusi yang ada ((Muriah, 2000). Cara mujadalah merupakan cara terakhir digunakan untuk berdakwahdengan orang-orang yang memiliki daya intelktual dan berpendidiakn tinggi dengan cara berwawasan uas dan bepikir maju kedepan (visioner) bahkan berdebat dengan orang ahli kitab.

Al-mujadalah al-ahsan merupakan upaya dakwah melalui bantahan, diskusi, atau berdebat dengan cara yang terbaik, sopan, santun, saling menghargai, dan tidak arogan. Dalam pandangan Muhammad Husain Yusuf, cara dakwah ini diperuntukan bagi manusia jenis ketiga. Mereka adalah orang-orang yang hatinya dikungkung secara kuat oleh tradisi jahiliyah, yang dengan sombong dan angkuh melakukan kebatilan, serta mengambil posisi arogan dalam menghadapi dakwah. Kesombongannya yang transparan mendorongnya untuk berkata: "Mengapakah al-Quran ini tidak diturunkan kepada orang-orang yang besar dari salah satu dari dua negeri (Mekah dan Thaif) ini".

Dalam al-Qurán Allah memberi perhatian khusus tentang berdebat dengan orang ahli kitab karena orang ahli kitab dibekali paham keagamaan oleh pendahulunya. Sebagaimana dalam Al-Qur'an Allah menjelaskan dalam QS. Al-Ankabut ayat 46:

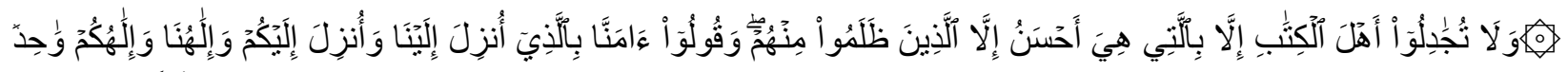

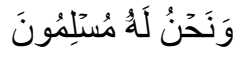

Artinya:

Dan janganlah kamu berdebat dengan ahli kitab (Yahudi dan nasrani) melainkan cara yang baik. Kecuali orang-orang zalim di antara mereka, (Quran Surah Al-Ankabut ayat 46).

Berdasarkan arti ayat diatas bahwa orang islam dilarang berdebat dengan orang yang beragama lain kecuali dengan cara yang baik, sopan, lemah lebut yang mencermikan sebagai orang islam kecualijika mereka berbuat zalim dan salah.

Maka dengan metode dakwah al-Mujadalah ini, maka dalam situasi dan demonstrasi harus dilakukan cara-cara diskusi dengan pihak yang terkait. Dilakukan berbagai cara seperti 
audiens dengan pemerintah sehingga aspirasi yang sampaikan dapat didengan langsung dan dengan cara berdiskusi untuk menemukan solusi yang baik tanpa merugikan kedua belah pihak. Banyaknya terjadi aksi demonstrasi anarkis karena dilakukan karena masing-masing pihak ingin menang sendiri. Maka dari itu, dibutuhkan metode diskusi sebagai cara terakhir karena yang dihadapi adalah orang memiliki intelektual yang tinggi.

\section{Faktor-Faktor Yang Menghambat Komunikasi Dakwah Terhadap Fenomena Demostrasi} Anarkis

\section{a. Aparat Keamanan Yang Bertindak Refresif}

Negara Indonesia sebagai negara berdasarkan hukum, namun di lapangan menunjukkan demonstrasi banyak yang mengabaikan norma hukum yang ada, seperti tindakan arogansi moral dengan merusak sarana dan fasilitas umum, melempar dan mengucapkan kata-kata yang kotor. Situasi dan kondisi ini disebabkan oleh kesalan dalam memahami makna kebebasan berbicara dan makna demokrasi dalam kehidupan masyarakat atau adanya tindakan yang tidak tepat dalam penanganan demonstrasi oleh pihak keamanan dalam hal ini kepolisian.

Sejak era reformasi di Indonesia, salah satu yang menjadi penanda adalah adanya keterbukaan dan kebebasan dalam berbagai segi kehidupan. Salah satu yang dapat dirasakan adalah adanya kebebasan dalam menyampaikan pendapat tanpa adanya rasa takut. Dalam kehidupan demokrasi yang semakin berkembang, membuat masyarakat lebih terbuka dan berani dalam menyampaikan aspirasi mereka. Dalam penyampaian pendapat di muka umum yang semakin mendapat tempat dan semakin sering terjadi, mulai dari demo oleh ormas, LSM dan bahkan buruh yang menuntut kenaikan gaji bahkan mahasiswa yang menuntut perbaikan kebijakan pemerintah sampai pada tuntutan untuk menurunkan presiden.

Dalam pelaksanaan demonstarsi dapat dilakukan dengan cara yang tertib dan damai akan tetapi dapat pula demonstrasi berkembang menjadi Gerakan yang cenderung agresif dan bahkan terkesan anarkis bahkan mengakibatkan kebrutalan. Ketika terjadi aksi demonstrasi tidak jarang tindakan pemukulan, pemaksaan, pengrusakan fasilitas bahkan tidak jarang terjadi penembakan kepada massa demonstran yang dilakukan oleh aparat keamanan.

Tindakan represif yang dilakukan oleh apparat keamanan terhadap demonstran yang terjadi salah satunya adalah demonstari mahasiswa tentang Revisi Undang-undang KPK dan revisi Undang-undang KUHP yang direncanakan akan dibahas oleh DPR RI. Mahasiswa menuntut agar pemerintah membatalkan Revisi Undang-undang KPK dan revisi Undang-undang KUHP tersebut karena akan merugikan rakyat dan menguntungkan pejabat yang tersandung kasus korupsi.

Demonstrasi yang terjadi di siang hari dengan cuaca yang sangat panas dan pihak keamanan yang bertugas dalam waktu yang cukup lama membuat pihak kemamanan cenderung lebih mudah melakukan tindakan agresif terhadap demonstarn. Setiap demonstrasi yang diamankan pihak kemanan cenderung menjadi ricuh menjelang sore hari sedangkan mereka sudah mempersiapkan tempat aksi demonstrasi dari pagi hari. Waktu yang lama dan suhu udara 
yang panas membuat subjek lebih cepat marah dan berbuat agresi terhadap demonstran. Tindakan agresi subjek dapat dijelaskan dengan pendapat Berkowitz (dalam Sarwono, 1997), yang mengatakan bahwa suhu udara dapat meningkatkan kecenderungan seseorang untuk bertindak agresi (Kurniat, 2008). Jadi, waktu dan cuaca dapat mempengaruhi psikologi pihak keamanan karena umumnya batas maksimal aksi demontrasi dilakukan sampai pada pukul 18:00 dengan cuaca yang sangat panas dan terik.

Aksi demonstrasi mahasiswa yang berlangsung hingga malam hari tersebut memaksa aparat keamanan dalam hal ini pihak kepolisian memaksa para demonstran untuk membubarkan diri atau menghentikan kegiatan demonstrasi karena sudah melampaui batas waktu yang telah ditentukan akibatnya terjadi aksi saling dorong antara pihak keamanan dan pihak massa demonstran bahkan terjadi pemukulan dan pelemparan ke massa atau ke pihak keamanan yang memicu tindakan represif oleh pihak keamanan.

Oleh karena itu, dibutuhkan tindakan-tindakan seperti soft approach oleh pihak keamanan maupun pihak massa demonstran dengan mengutamakan komunikasi yang persiasif dalam hal ini komunikasi dakwah yang dapat menenangkan massa demontran. Komunikasi dakwah tersebut adalah dengan lemah lembut dan tidak memancing kemarahan dari pihak keamanan maupun pihak massa demonstran.

Inilah yang menjadi salah satu faktor penghambat komunikasi dakwah terhadap fenomena demonstrasi anarkis karena antara kedua pihak yaitu pihak keamanan dan pihak massa demontrasi saling mengedepan arogansi tanpa memperdulikan faktor lain yang dapat merugikan pihak yang lainnya.

\section{a. Politisasi Gerakan}

Dalam konteks Gerakan, isu-isu tentang perubahan, revolusi dan reformasi dalam sebuah negara selalu dikaitkan dengan mahasiswa. Dengan nama besar mahasiswa, mereka telah menunjukkan nama besar sebagai simbol dan ikon di balik sebuah perubahan di seluruh penjuru dunia. Di Indonesia dalam konteksnya pun demikian. Berbagai macam perubahan yang telah dilakukan yang cukup pendamental yang hampir semua dimotori dan diprakarsai oleh mahasiswa. Gerakan mereka baik dalam konteks demonstrasi maupun dalam bentuk tekanan-tekanan lainnya yang telah melahirkan sebuah gerakan reformasi yang mengakibatkan jatuhnya rezim Soeharto pada tahun 1998. Perubahan rezim kepemimpinan tersebut tidak lepas dari peran mahasiswa. Gerakan mahasiswa yang begitu massif dan tajam sehingga dapat mengubah suatu kebijakan yang dinilai tak memihak kepada rakyat.

Di era sekarang ini, perbedaan pandangan tentang Gerakan mahasiswa sebagai Gerakan moral atau Gerakan politik mulai agak naik turun sehingga mulai terdengar biasa-biasa saja. Ini diakibatkan oleh hegemoni Gerakan yang membuat para mahasiswa menjadi terlena apalagi seringnya terjadi politisasi gerakan. Politisasi gerakan ini biasanya ditunggangi oleh pihak-pihak tertentu yang mempunyai kepentingan pribadi sehingga dapat mencederai nilai sebuah gerakan.

Gerakan yang ditunggangi atau dipolitisi merupakan sebuah gerakan yang dapat mencederai nilai-nilai perjuangan. Gerakan yang dinilai tidak murni yang lahir dari hati nurani untuk sebuah 
perubahan tetapi karena faktor lain yang tidak sesuai dengan tujuan di balik sebuah perjuangan. Gerakan yang tidak murni ini disebut "Pseudo". Pseudo sendiri berasal dari Bahasa Yunani yang berarti "palsu". Prefix ini digunakan untuk mendakan sesuatu sebagai hal yang semu, pemalsuan, penipuan, dalam penelusuran situs artikata.com. pseudo memaknai "a person who makes deceitful pretenses" (seseorang yang membuat kepura-puraan yang menipu), (Kosasi dan Ilyas, 2013: 32).

Dalam hal ini, Gerakan yang semu yang penuh dengan kepura-puraan dapat mencederai arti sebuah Gerakan yang berangkat dari hati Nurani dengan tanggung jawab moral. Dalam konteks sekarang ini, beberapa gerakan aksi demonstrasi dinilai sebagai kepura-puraan, kepalsuan atau Pseudo baik itu gerakan dari mahasiswa, LSM maupun ormas lainnya. Pasalnya, gerakan yang dilakukan bercampur antara kepentingan memperjuangkan rakyat atau kepentingan pribadi tertentu.

Gerakan yang dilakukan seringkali tidak murni sebagai suatu gerakan yang tidak berdasarkan pada nilai-nilai perjuangan. Gerakan yang cenderung pragmatis sehingga menguntungkan beberapa pihak tertentu. Gerakan yang didasari oleh pragmatis, maka akan sama dengan gerakan yang tidak idealism, padahal idealism adalah harta yang paling berharga bagi seorang demonstran. Aksi yang dilakukan dengan berdasar pada pragmatis dengan menggadaikan idealism akan merusak suatu gerakan dengan penuh kepalsuan.

Oleh karena itu, gerakan yang murni atas dasar perjuangan moral yang berangkat dari hati nurani dapat meminimalisir terjadinya politisasi gerakan dan fenomena terjadinya aksi demonstrasi yang berujung anarkis tidak akan terjadi apabila komunikasi dakwah berjalan dengan baik yang berasas dari nilai-nilai Islam.

\section{b. Tindakan Propaganda dan Provokasi}

Secara etimologi, menurut Kamus Besar Bahasa Indonesia, propaganda berarati penerangan (paham, pendapat, dan sebagainya) yang benar atau yang salah, yang dikembangkan dengan tujuan meyakinkan orang banyak agar menganut suatu aliran paham, sikap atau tindakan tertentu; biasanya disertai dengan janji yang muluk-muluk. The Grolier International Dictionary, mengartikan propaganda sebagai penyebaran secara sistematis doktrin tertentu atau pernyataan yang direkayasa, yang merefleksikan suatu aliran pikiran, pandangan, atau kepentingan (Shoelhi, 2012). Perbuatan ini dapat mnumbulkan suatu tindakan yang dapat merusak jika digunakan dengan tujuan yang salah.

Tak jarang ditemukan tindakan propaganda dalam suatu aksi demonstrasi yang dilakukan baik mahasiswa, LSM maupun ormas bahkan buruh. Tindakan ini memicu terjadinya tindakan anarkis dalam suatu kondisi. Ini akibat dari ketidakmampuan dalam mengkoordinir massa aksi yang begitu banyak sehingga massa dengan mudah terprovokasi dan memicu aksi tindakan anarkis.

Salah satu pemicu terjadinya tindakan anarkis dalam suatu aksi demonstrasi adalah adanya tindakan provokatif oleh oknum-oknum provokator yang tidak bertanggung jawab dan menginginkan sebuah gerakan aksi demontrasi agar tidak berjalan dengan baik. perilaku 
provokatif dari massa aksi demonstrasi tersebut merupakan perilaku yang tidak diinginkan dan mengancam kepentingan dan tujuan bersama.

Dalam kamus besar Bahasa Indonesia, provokasi adalah perbuatan untuk membangkitkan kemarahan, tindakan menghasut; penghasutan; pancingan. Tindakan provokasi ini dampak yang ditimbulkan adalah mengundang kemarahan yang berasal dari penghasutan yang dapat mengakibatkan kerusuhan bahkan mengakibatkan pertumpahan darah.

Provokasi memiliki dampak yaitu dapat menyebabkan adanya salah paham, terjadi pencemaran nama baik, atau yang lebih ekstrim lagi yaitu menimbulkan rasa kebencian dan rasa dendam. Pencegahan aksi provokasi yaitu dengan cara menyaring segala informasi yang masuk dengan bersikap rasional, tenang dan selektif dalam mencari data dan informasi terlebih dahulu dari segala bukti sehingga informasi tersebut dapat dibenarkan.

Tindakan yang memicu aksi anarkis yang berawal dari propaganda yang mengakibatkan timbulnya aksi provokasi sehingga memicu terjadi aksi anarkisme. Tindakan ini dapat mencederai suatu gerakan yang murni yang berangakt dari nilai moral dan nilai-nilai luhur dari sebuah perjuangan demi kemaslahatan rakyat karena pada sejatinya aksi demonstarsi berangkat dari keresahan rakyat.

Berdasarkan pengalaman yang terjadi di lapangan, bahwasanya aksi anarkisme aksi anarkisme terjadi karena adanya provokator yang memanfaatkan situasi dan kondisi yang terjadi dimana massa aksi yang kurang terontrol sehingga dengan mudahnya terpancing oleh keadaan. Begitupun sebaliknya, pihak keamanan yang menjaga di lokasi aksi ikut terpancing oleh oknumoknum yang tidak bertanggung jawab sehingga kedua belah pihak saling terpropokasi akibat dari propaganda yang dilakukan oleh beberapa massa aksi.

Oleh karena itu, dalam melakukan kegiatan aksi demonstrasi, hal yang sepatutnya diwaspadai adalah adanya provokator dalam gerakan aksi agar tidak memicu terjadinya aksi anarkis. Dibutuhkan komunikasi yang baik antara pihak massa maupun pihak keamanan agar tercipta aksi demonstrasi yang damai dan menyejukkan meskipun suasana panas karena dalam kondisi tersebut dibutuhkan suasana hati yang sejuk dan dihadapi dalam kondisi kepala dingin.

\section{Simpulan}

Dalam meminimalisir terjadinya demonstrasi anarkis maka dibutuhkan pendekatanpendekatan yang islami dengan metode dakwah yaitu, al-hikmah, al-mauzah al-hasanah dan almujadalah. Dengan metode pendekatan tersebut, maka dapat meminimalisir terjadinya anarkis sehingga pesan-pesan yang disampaikan oleh dai (demonstran) bisa tersampaikan dengan tepat diterima dengan bijak oleh pemangku kebijakan. Faktor penghambat komuniasi dakwah terhadap fenomena demonstrasi anarkis adalah aparat keamanan yang bertindak refresif terhadap demonstran sehingga mengakibatkan terjadinya aksi anarkis sehingga terjadi politisaasi gerakan dan dapat mencederai nilai-nilai perjuangan, tindakan proraganda dan prvokasi yang dimotori oleh oknum-oknum yang tidak bertanggung jawab yang menginginkan aksi demonstrasi tidak berjalan dengan baik dan lancar. Aksi demonstrasi menjadi bukti kepedulian terhadap kondisi bangsa dan negara. Demonstarsi harus mempertimbangkan aspek-aspek sosial masyarakat yang 
memiliki karakter tersendiri khususnya aksi demontrasi yang berujung pada anarkis. Makalah ini tidak bisa membahas secara keseluruhan yang diinginkan. Oleh karena itu, setelah makalah atau penelitian ini ada tindak lanjut dari pemakalah selanjutnya yang membahas komunikasi dakwah dan fenomena demonstrasi anarkis.

\section{Referensi}

Abdussalam. (2006). Kemerdekaan Menyampaikan Pendapat di Muka Umum. Jakarta: Restu Agung.

Sapari, A \& Kurniat, N. T. (2008), Gambaran Agresivitas Aparat Kepolisian yang Menangani Demonstrasi. Jurnal Psikologi. Volume 1, No. 2, Juni 2008.

Cangara, H. (2016). Pengantar Ilmu Komunikasi. Jakarta: PT. Rajagrafindo Persada.

Chomsky, N. (1970). “Introduction”. Kata Pendahuluan untuk buku Daniel Guérin, Anarchism From Theory to Practice. London: Monthly Review Press.

Hasse, J. (2012). Anarkisme Demonstrasi Mahasiswa: Studi Kasus Pada Universitas Islam Negeri Alauddin Makassar Jurnal Studi Pemerintahan Vol.3 No.1 Februari.

https://www.liputan6.com/citizen6/read/3869107/sara-adalah-isu-sensitif-berikut-arti-danpenjelasannya

Kementrian Agama RI. (2009). Al-Quran dan Terjemahnya, Bandung: PT. Sygma Examedia Arkanleema.

Kosasi, A \& Ilyas, M. (2013). Pseudo Gerakan Mahasiswa. Jakarta: Insan Madani.

Munir, M. \& Ilaihi, W. (2015). Manajemen Dakwah. Jakarta: Prenada Media Group.

Muriah, S. (2000). Metode Dakwah Kontemporer. Jakarta: Mitra Pustaka.

Ngalimun. (2017). Ilmu Komunikasi Sebuah Pengantar Praktis. Yogyakarta: PT. Pustaka Baru.

Ismail, A. I \& Hotman, P. (2013), Filsafat Dakwah Rekayasa Membangun Agama dan Peradaban Islam: Prenada Media Group.

Seha, S. (2012). Paradigm Dakwah Menata Ulang Penerapan Dakwah di Indonesia. Makassar: Alauddin University Press.

Shoelhi, M. (2012). Propaganda dalam Komunikasi Internasioanl. Bandung: Simbiosa Rekatama Media.

Sukayat, T. (2015). Ilmu Dakwah Perspektif Filsafat Mmabadi Asyarah. Bandung: Simbiosa Rekatama media.

Tike, A. (2011). Dakwah dan Pengembangan Masyarakat Islam. Makassar: Alauddin University Press.

Undang-Undang Nomor 9 Tahun 1998 